\title{
Planning post-summurbia: From spontaneous pragmatism to collaborative planning?
}

\author{
Mari NUGA a *, Pille METSPALU a, Anette ORG a , Kadri LEETMAA a
}

\begin{abstract}
The possibilities to apply collaborative planning frameworks in formerly strictly planned areas that have experienced spontaneous transformations since the demise of the Soviet Union are examined in this paper. The enquiry is based on a case study of the Tartu region in Estonia, former socialist summerhouse settlements ('summurbia'), which are experiencing a transition towards permanent residence resulting in a new yearround form of suburbia. Both the residents and local planning authorities were interviewed in order to understand the prevailing planning and building activities, as well as the social relations between these stakeholders. The collaborative planning process is then elaborated by exploring the social dynamics and learned practices of the local residents.
\end{abstract}

Keywords: summerhouses, suburbanization, pragmatic planning, collaborative planning, Tartu, Estonia

\section{Introduction}

The conditions for collaborative planning practices to be used in suburban residential areas that have deep roots in Soviet planning practices, and which have been spontaneously transformed during the post-socialist years, are examined in this article. Estonia, like the rest of the demised Soviet regime, suffered from economic hardships associated with the collapse of the command economy. As a result, there emerged serious conflicts and contradictions between the comprehensive and top-down planning system that characterized the Soviet economy, and the post-1991 market-led developments, which required deregulation and decentralization (Roose and Kull, 2012; Tsenkova, 2010 and 2014). Indeed, the planning discourse in post-socialist cities has centred on a number of conflicts: comprehensive vs. pragmatic planning; centralized vs. decentralized decision-making; top-down vs. bottom-up approaches; and interventionist vs. entrepreneurial marketdriven, planning (Altrock et al., 2006; Hirt and Stanilov, 2009). In order to keep up with contemporary 'western' planning theories, more strategic, including collaborative, planning approaches have also been applied at various levels (Simpson and Chapman, 1999; Golubchikov, 2004; Hirt and Stanilov, 2009). Nevertheless, the planning-related literature on the Central and Eastern European (CEE) region is mostly limited to the abstract level, and is characterized by a relative scarcity of concrete case studies. Our article addresses the latter gap through an in-depth examination of a particular suburban milieu, allowing for a deeper understanding of the challenges facing planners in the present stage of postsocialist transformation.

Our study area consists of socialist-era summer house settlements that were originally planned as seasonal destinations for urban dwellers. We refer to these areas as 'summurbia' to reflect their simultaneous suburban and summer-seasonal nature. Although we focus on one post-Soviet planning example in Estonia, these areas are a near-ubiquitous feature of the urban regions of postsocialist countries (Ioffe and Nefëdova, 1998; Fialová, 1999; Pócsi, 2011; Vágner et al., 2011). Summurbia represents the strict planning and functional regulations that characterized the socialist years. Additionally, situated in the suburban zones of cities, these settlements are good examples of the rapid and liberal post-socialist development that has taken place over the last 25 years (cf. Hirt, 2007; Ouředníček, 2007; Leetmaa et al., 2012). Contemporary 'post-summurban' milieux typically combine modern suburban living with remnants of the dacha culture of the still recent socialist past (see Fig. 1).

This article focuses on how residents and local municipality officials relate to planning issues in post-summurbia. We chose a research strategy built on qualitative interview methods, as we view these as essential to provide personal insights into the ideas, needs and visions of our informants towards permanent residence in post-summurbia. While mapping out the planning arena from the perspectives of local planning officials and post-summurban residents, the article gives special recognition to the lack of rules and principles that have emerged. In contrast, principles are a fundamental feature of planning as a common governance practice (cf. Healey, 2009). In our discussion of the case studies, we view the absence of proactive planning as a form of 'spontaneous

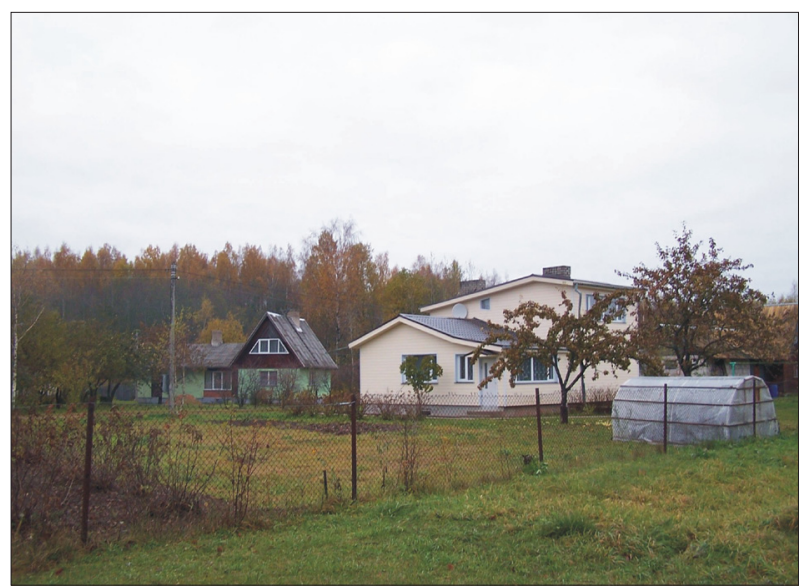

Fig. 1: Post-summurban milieux (Photo: A. Kährik, 2009)

\footnotetext{
${ }^{a}$ Department of Geography, Institute of Ecology and Earth Sciences, University of Tartu, Tartu, Estonia; (*corresponding author: M. Nuga, e-mail:mari.nuga@ut.ee)
} 
pragmatism', which evolved through the residents' activities and actions. By 'spontaneous pragmatism', we refer to the planning principle of pragmatism-incrementalism (Næss, 2001) which brings us back to one of the foundational ideas of collaborative planning (Healey, 2009).

Our account proceeds with a discussion of the relevant planning theory relating to suburbia, setting the theoretical context for the subsequent description of past and present planning practices in the case study area, and allowing us to frame our research questions. Then, after presenting our case study locale and methods, we continue with the results of our interview study.

\section{Theories of suburban planning}

The planning of suburban areas has a long and varied history, rendering it difficult to identify unified experiences of suburbanization. Instead, researchers and planners must come to terms with a variety of planning frameworks and approaches. Broadly speaking, suburban homes tend to be either built: (i) systematically, to the specifications of the owner, or indeed by the owner over time; or (ii) by developers and builders on the neighborhood, municipal, or regional scale (Forsyth, 2012). Hence, these two approaches echo the two most prominent planning methodologies, respectively, the pragmatic-incrementalist, where suburbs are allowed to expand spontaneously, and the rational-comprehensive approach, through which suburban areas are master-planned as neighbourhoods or communities (Rosenhead, 1980).

Incrementalism is described as "one bite at a time" planning (Næss, 2001: 513). It arises from the philosophical idea of pragmatism that states that there should be no rules for planning and that everything should be discovered and asserted in the flow (Healey, 2009). In this way, the consideration of alternative goals and policies is only marginally different from the status quo, and the examination and comparison of different alternatives are relatively simplified. The results are thus experimented as in social situations rather than built in theories. As Healey (2009: 287) puts it: “... the pragmatists insist on focusing transformative attention in the flow of practice and the practical challenges and puzzles that are continually confronted in the particularities of practices". Following this approach, the planner would see no value in comprehensiveness, preferring instead to deal with problems as they arise. By relying on such small steps and cycles of learning and adaptation, the more restrained incremental approach has been recognized as the antithesis of planning (Kemp et al., 2007). At the same time, as a planning approach it still takes into account that it has to "address the difficulties created by the complex collocations of activities and their relations and the impacts these collocations generate across space-time" (Healey, 2009: 277).

In contrast, the rational-comprehensive methodology, which is based on positivist theories, offers a comprehensive planning process that is logical, consistent, and systematic, and it follows an idealized 'analysis-problem-solution-implementation' planning model (Lawrence, 2000). The rational-comprehensive approach in its pure form emphasizes predictability and seeks to eliminate such aspects as uncertainty, human fallibility and indecisiveness (Rosenhead, 1980). In the context of the present study, rational positivist planning is seen as a basis for Soviet and socialist planning (French, 1995; Smith, 1996).

In principle, the incrementalist and rationalcomprehensive approaches have been used concurrently throughout the history of suburbia in Western countries, with the dominance of one or the other determined by the idiosyncrasies of the prevailing social, economic and institutional setting. The growing concerns over environmental and sustainability issues that emerged in the 1980s, however, affected both styles: therefore, planners turned to mixed land use, connected street patterns and pedestrian-friendly communities (Grant, 2009), and to developments that favoured amenity-rich and sustainable urban lifestyles (Danielsen et al., 1999), as well as traditional neighbourhood designs (Duany et al., 2000). Armed with these principles, planners pushed through such strategies and ideas as smart growth, liveable communities and new urbanism, gradually introducing them into suburban planning throughout the West.

In parallel with the upsurge of interest in sustainability issues, another new approach attracted the attention of planners in the 1990s. Realizing that planners typically mediate between various interests, planning theorists acknowledged the existence and encouraged the development of 'collaborative', 'communicative', or 'community planning', which emphasize communication, participation, and consensus-building throughout the planning process (Forester, 1989; Healey, 2003; Innes and Booher, 2010). This approach combines incrementalist and comprehensive planning, as it simultaneously deals with the everyday issues of the participants and puts together longterm strategies and goals. The most important contribution of collaborative planning theorists was therefore that the claim that planning would only be successful if its stakeholders were able to participate in the process in a meaningful way. Many aspects of the collaborative approach are laudable. Firstly, it recognizes the multiplicity and diversity of planning stakeholders within an increasingly complex, pluralist, and unpredictable world. Secondly, it adopts a holistic perspective towards development and accepts the implicit value of subsidiarity. Thirdly, it involves an informed and engaged citizenry in the settlement of disputes (Brand and Gaffikin, 2007).

The largely enthusiastic reception that greeted the communicative approach in urban planning in the 1990s, however, was accompanied by both a questioning of the theory and suggestions on how to improve it (Allmendinger and Tewdwr-Jones, 2002; Healey, 2003). In particular, the fact that planning practice rarely reflects the qualities of a potential collaborative process, fuelled some criticisms of the overall conceptualization and practical relevance of the collaborative planning idea (Huxley and Yiftachel, 2000). For example, Healey (2003) argues that authoritative and allocative "systems" operate within the interactive process of planning, which suggests that these systems depend not only on the interplay of different actors with specific interests, but also on the way in which routine social relations and practices are structured through institutional designs and deeper values and conceptions. Indeed, collaborative planning theorists strictly emphasize taking account of the concrete settings in which planning takes place, which relates back to the incremental-pragmatic philosophies and practices of planning (Healey, 2003, 2009).

In this regard, post-summurbia offers an interesting setting to study the potential of collaborative planning, relating it back to its roots in the incremental approach. In order to better understand the background of this setting, we continue by introducing the planning history and context of post-summurbia. 


\section{Summurbia: an anomaly of socialism and a hallmark of post-socialist planning}

\subsection{Summer houses from the socialist planning perspective}

In the Soviet Union, the task of planning was to command and allocate: regional and urban planning were subservient to the complex hierarchy of central economic planning (Shomina, 1992; French, 1995). Detailed and strict rules produced in Moscow regulated planning activities in Estonia. The urban and regional Executive Committees (gorispolkom and rayispolkom, respectively, in Russian) were responsible for the plans to be fulfilled, but they had little influence on their contents.

Hence, urban and regional planning was largely a technical exercise. Planners, who were trained as architects or engineers rather than as overseers of social change, translated the detailed instructions into finished designs for, say, a complex of settlements, a particular city, or a city district (Hirt and Stanilov, 2009; Golubchikov, 2004, 2006). The rayispolkom ordered planning projects from the Union-Republic's Building Committee. The latter, in turn, organized competitions for architectural designs and created detailed solutions for the specific objects. All the detailed plans, e.g. plans for private houses, were examined by the committee of experts on architecture, fire safety and sanitary issues, and each project required the consent of the electricity provider (Bruns, 2007).

The plans were not required to be made public, and planning documents (including, not least, the genplan or master plan itself) were usually secret or for official use only. Still, in Estonia, by the end of the Soviet period, the plans were more and more discussed in public (Bruns, 2007). Despite its lack of democracy, transparency, and accountability, socialist planning has been recognized for its ability to restrain urban sprawl and as conscious towards nature preservation in general (Bater, 1980; French, 1995).

Our summurban case study areas were typically created around larger cities to provide a way for some urban dwellers particularly apartment dwellers (French, 1995) - to enjoy weekend getaways and summer living, and to engage in private kitchen gardening (Ioffe and Nefëdova, 1998; Lovell, 2003). Although this "individualist" recreation function of the dachas (as the summer houses are called in Russian) was not considered to be genuinely socialist because of its excessive proximity to the concept of 'private property', it was tolerated by the authorities mainly because of its long tradition in Russia (Shaw, 1979). Moreover, it effectively helped counter the effects of the food shortages that were a relatively frequent occurrence in the Soviet Union. In more contemporary research literature, the summer house settlements have been referred to in using the concepts of seasonal or recreational suburbanization, quasi-suburbanization, or even exurbanization (Ioffe and Nefëdova, 1998; Lovell, 2003; Rudolf and Brade, 2005). Wanting to stress both the seasonal and the suburban nature of the settlements, we choose to refer to them by the concept of 'summurbia'.

To better understand the historical background of our case study districts, our lead author interviewed two experts that have been working for the Estonian Building Committee, Anne Siht (2011) and Eve Niineväli (2011). Both were involved in establishing the summer house settlements between the 1960s and 1980s.

In accordance with the rest of the planning and building activities of the Soviet period, summurbia was established following commands from Moscow, with the more detailed decisions about the size and location of the developments decided upon by the rayispolkom (Siht, 2011). Summurbia was planned in a technically detailed way. It was not built on good agricultural land, but rather on fields that were not accessible to large agricultural machinery. The land used for settlements consisted mainly of wild brushy $600-1100 \mathrm{~m}^{2}$ wetland plots (Niineväli, 2011; Siht, 2011). Each settlement typically included many 'cooperatives' (a set of plots) that were combined by the members of work places or trade unions.

The allocation of the summer house plots took place as follows. The work places and trade unions where the cooperatives were formed, applied for the land from the rayispolkom. After the land was provided, the Building Committee was responsible for putting together the detailed plan, covering the subdivision of the plots, main roads, water wells, drainage, and electricity supply (Niineväli, 2011). The cooperative members could meet with the chief architect in a social gathering in order to choose the design of the buildings from up to 50 standard designs, asking for adjustments (Siht, 2011). The architect then arranged the summer house buildings into suitable combinations, taking the surrounding environment into consideration - e.g. a pitched roof was combined with the spruce forest on the edge of the settlement (Siht, 2011). The construction-related activities, including clearing the area of shrubs and building the huts and fences were carried out by the summurbanites themselves (Niineväli, 2011; Siht, 2011). The building activities were controlled by the other cooperative members and their coherence with the plan was every now and then inspected by the respective authorities (Siht, 2011).

Although the maximum permitted building size gradually increased over time, plot-owners still found ways to circumvent the regulations (Siht, 2011; Niineväli, 2011), resulting in a spontaneous evolution from garden cooperatives (which only permitted small huts or shacks) to modest summertime settlements. Already during Soviet times, some people moved to their summer houses permanently; and creativity and self-reliance became commonplace. Although comprehensive, planning could not fully control the activities that took place in summurbia, people adjusted their summer houses in accordance with their dreams and available resources (Niineväli, 2011). In this regard, we consider summurban settlements to be anomalies within the socialist system of central planning.

\subsection{Post-socialist 'twists' in planning}

Socialist ideology and planning vanished during the early years of the post-1991 market transition, favouring the rise of a liberal planning regime characterized by "boosterism" (Ruoppila, 2007) and ad hoc pragmatism (French, 1995). Many Soviet norms and regulations - even the reasonable ones - were vigorously rejected. Even now, when the Planning Act regulating planning affairs has been adjusted several times since its first adaption in 1995, there are only a few concrete norms and rules. Nevertheless, Estonian national planning is "rooted in rational thinking and technocratic management promoting straightforward, command-and-control solution-oriented plans", as was the common practice during Soviet times (Roose and Kull, 2012: 498). Planning is still managed by a wide range of professionals instead of by specifically trained planners (Adams et al., 2014).

During the transition, most post-socialist countries embarked on a path towards administrative decentralization and increased self-government at the local level (Hirt and 
Stanilov, 2009; Tsenkova, 2011). The main responsibility for planning, including detailed residential planning, was assigned to the local authorities that were newly empowered but financially poor (Simpson and Chapman, 1999; Samarüütel, et al., 2010). Also, in Estonia, more general plans for the country and the regions are rather visions that could be easily amended in accordance with local needs (Roose and Kull, 2012).

One of the main changes in the planning context, and for residential planning more specifically, was the fact that private property was reintroduced, and public interests may no longer impose restrictions on private property. Both the general mistrust about planning that lingered on from Soviet times and low public interest and participation encouraged the development of liberal and eclectic legislation (Simpson and Chapman, 1999; Tsenkova, 2011). This trend, in turn, resulted in a period of institutional uncertainty (Raagmaa, 2009). An ad hoc approach in which planning initiatives were developed with few resources, little time and little attention to strategic thinking, emerged in Estonia during the first half of the 2000s, when the national economy developed steadily (Roose and Kull, 2012). During this period, residential suburbanization boomed, following a trend that characterized many post-socialist countries (Ouředníček, 2007; Brade et al., 2009; Tammaru et al., 2009).

Most summurban plots were privatized, and the gradual conversion of simple huts into solid suburban residences for use in all seasons gained momentum (cf. Mason and Nigmatullina, 2011). At present, post-summurbia is diverse: although many residents live there permanently, some houses are used as second homes, while a few plots are simply deserted (Leetmaa et al., 2012). The territory offers a variety of visual impressions: one may find genuine ("untouched") and renovated Soviet summer huts, buildings at various stages of construction or renovation, simple single-family housing, and the occasional architectural faux pas design(at) ed for the new rich (see Fig. 2).

Summurbia, however, received little attention from planners, and it was and is being transformed in an unregulated fashion. Conveniently for local municipalities, the now year-round residents of the former summurbia are already accustomed to coping on their own. Moreover, the habit of challenging high-level planning regulations facilitated residents' independent approach to make and manage changes in post-summurbia.

This trend pushes us to view these areas as the epitome of post-socialist planning and interpret planning in these areas through the lens of 'spontaneous pragmatism'. While not grounded in the philosophy of pragmatism per se, the concept of spontaneous pragmatism captures the spontaneous changes, lack of comprehensiveness and ad hoc approaches that permeate the literature on planning in the post-socialist context (Altrock et al., 2006; Hirt and Stanilov, 2009).

Next, we look into our specific case to describe this context in detail and discuss the possibilities for changing the contemporary situation in post-summurbia into planning based on more collaboration. We formulated the following main research question:

- How can the current understanding and discussions surrounding planning in post-summurbia foster collaborative planning?

To provide a comprehensive answer to this question, we addressed the following sub-questions:

- What characterises spontaneous pragmatic planning in post-summurbia?

- What are the experiences and practices of communication in post-summurbia between the residents and authorities?

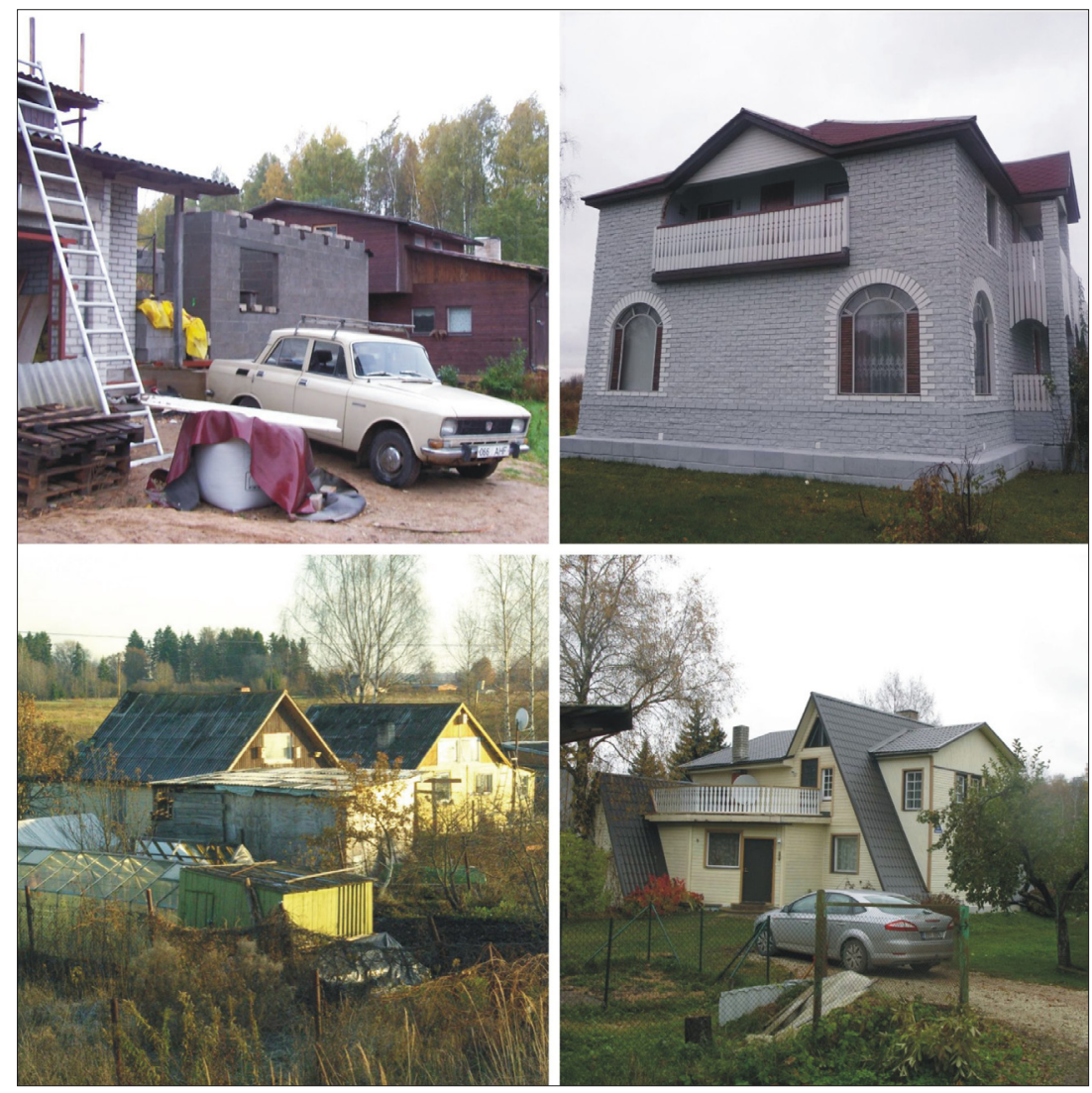

Fig. 2: Examples of the visual impressions from post-summurbia (Photo: A. Kährik, A. Org and H. Lainjärv, 2009) 


\section{Study design}

Our research took place in the Tartu urban area. Tartu is the second largest city in Estonia with approximately 100,000 inhabitants in the core city. The vast majority of the post-summurban settlements are located within a $40-\mathrm{km}$ radius of the city limits (Fig. 3). There are approximately 3,000 summurban plots around the city (Fig. 4). The most intense new suburbanization is observable within $10 \mathrm{~km}$ of the Tartu city limits (Roose et al., 2013), which also affects the summurban settlements located within this radius to a greater degree (Fig. 4). The scale and extent of suburbanization around Tartu are comparable to similar processes surrounding comparable cities across the post-socialist realm (Roose et al., 2013).

In spring 2010, one of the authors of this paper conducted 19 informally structured in-depth interviews with municipal officials from all municipalities that include summurban settlements within the Tartu region. The interviewed officials were responsible for property affairs, environmental issues, or were experts in building and construction in their respective municipalities.

The interviews focused on the following three topics: (i) post-summurban residents' relations with the municipality; (ii) the main problems related to post-summurbia; and (iii) officials' planning visions for these areas.

In addition to these expert interviews, we have conducted twenty-one interviews with permanent post-summurbanites in the Tartu region in autumn 2009. This endeavour was part of a wider interview study that aimed at understanding the reasons people decided to move to former summer areas (Leetmaa et al., 2011). The interviews were carried out by five interviewers (three of us are the authors of the current article). One of the interviewers spoke in Russian, in order to address the preferences of the significant

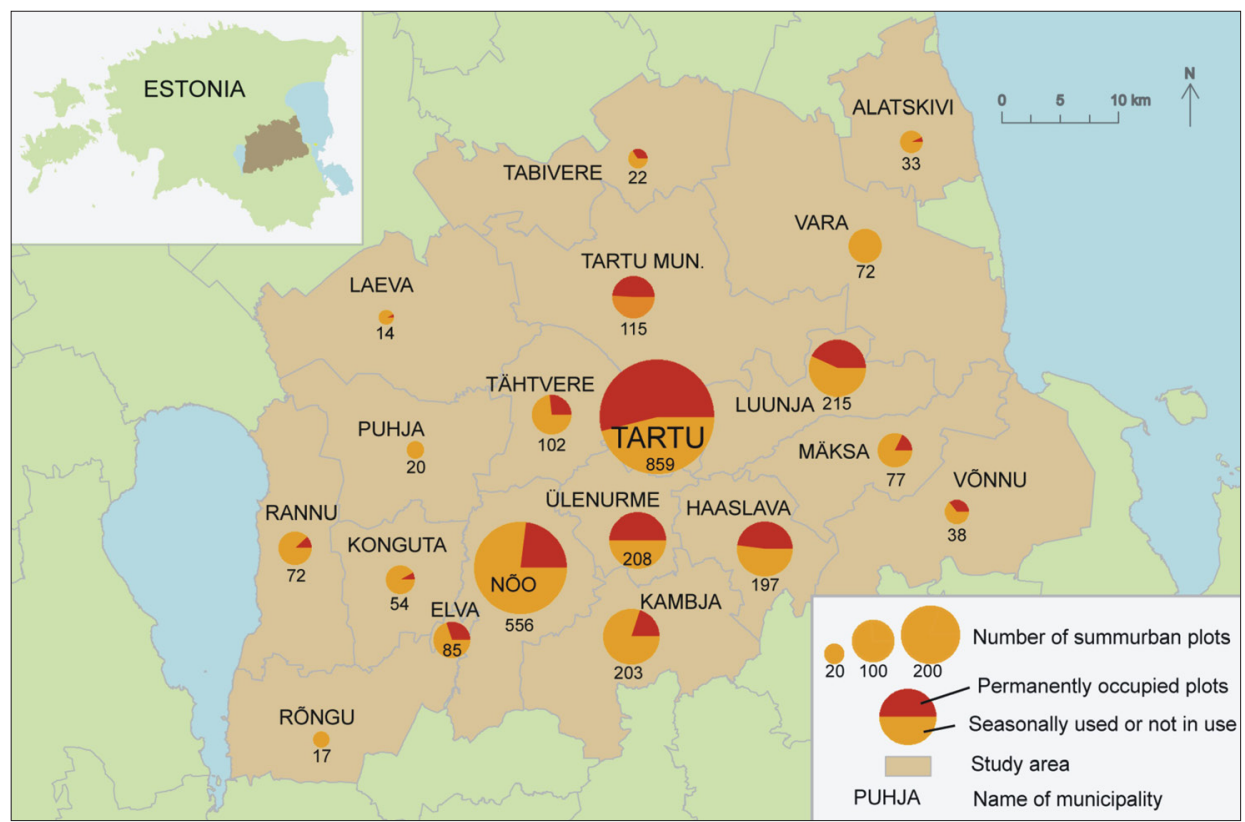

Fig. 3: Share of permanent residents in post-summurbia by municipality. Data is estimated by the interviewed municipality officials

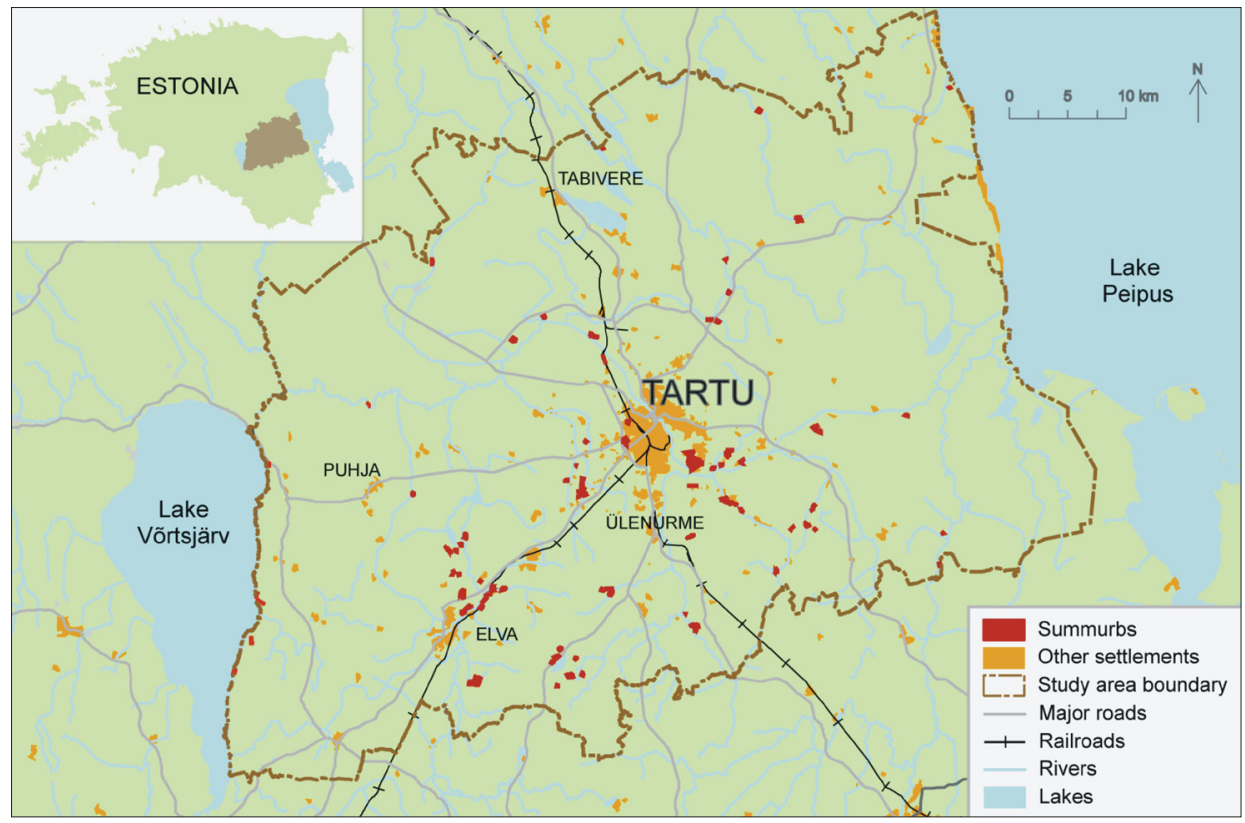

Fig. 4: Locations of summurban settlements in the Tartu region 
Russian-speaking ethno-linguistic minority present in the country. The participants were selected based on two criteria: (i) geographical location (in relation to Tartu) and morphological characteristics of the settlements, and (ii) the physical condition of the specific buildings occupied by (potential) informants. The latter was assessed based on the degree of renovation (original summer house, renovated summer house, or new house). This approach enabled us to capture the diversity of the residents' living milieux and also the diversity of possible planning-related ideas.

The resident participants were approached door-to-door, and in only a few cases did the approached persons refuse to cooperate, and people were overall very open to participate. Interviews were conducted on the spot, either immediately or by later appointment, and lasted about one hour.

All interviews were recorded, transcribed and coded. Open coding was applied to the text as the first step, in order to avoid imposing an outside set of categories and to get as close as possible to emic knowledge (Crang and Cook, 2007). These codes were categorized during the intuitive interpretation of the interview transcripts, keeping in mind the planningrelated research questions.

The interview data presented us with a diversity of opinions and ideas relating to the planning-context of the settlement. Eventually, with an increasing number of overlapping opinions, our study approached saturation in relation to our main aim.

We combine the views of the summurbanites and of the municipality officials in the following two sections. The first section (5.1) describes the planning situation and building activities in post-summurbia in order to elaborate on the residents' and planners' learned customs for living and solving (planning) problems. Moreover, it offers novel insights into the specific context of socialist history and postsocialist change that influences the planning process. The second section (5.2) describes the social dynamics that are unfolding in post-summurbia. It also presents the basis for barriers to developing a communicative planning approach in such settlements.

\section{Findings of the study}

\subsection{The spontaneous pragmatic approach in post-summurbia}

Self-sufficiency is a principal feature of life in postsummurbia. A topic frequently raised by residents was how they proudly self-manage everything at home and in their neighbourhoods. As mentioned earlier, summurbanites prepared, cleared, and built on their plots themselves. Further, households make their choices carefully after weighing the advantages and disadvantages of living in post-summurbia, especially with respect to its inadequate infrastructure:

When you live in the countryside, you have to take into consideration that sometimes the roads are impassable and the power supply is down. You just have to manage (middleaged married man, int. R16).

The residents of post-summurbia perceive their lives as rural and beyond the need of interference by classical settlement planning. It is also worthy of note that the municipal building regulations on design and (re) construction are minimal. Commonly, they do not stretch beyond an approximate building height or function. Sometimes, municipal planners are satisfied with just any reconstruction and are either unable or unwilling to issue more specific building regulations. Similarly, former summer huts are commonly rebuilt by the residents themselves, with only more specialized work being paid for. Indeed, only a few of the interviewed households had settled into a ready-made dwelling. According to them, their homes are often neverending creative building projects inspired by their own dreams. As one of our participants told us:

My main activity here is to redesign the house... There are always more ideas than time to fulfil them (middle-aged woman living alone, int. R18).

Such activities have led to the areas being developed in a unique, alternative, and somewhat chaotic way. Structures built some years ago may be redeveloped into something that has quite a different purpose, for example, into a garage or a sauna. This is in stark contrast to the socialist period, when the ubiquitous concrete architectural schemes could be changed only marginally - and then only with the prior consent of the authorities (Niineväli, 2011). A corollary of such self-management is that residents can regulate how much they spend on everyday expenses such as heating, water, garbage collection, and so forth.

A closer look at post-summurbia, however, reveals a number of problems related to the deficiencies of the general infrastructure, including the water supply, sewerage and drainage, waste management, power lines, and roads. Even though these problems are present elsewhere too, no planning guidelines have been devised to solve them, so the residents have started to look for temporary solutions. In addition to building and renovating their own homes, residents have dug wells, built sewerage systems, and even constructed shared roads:

We built our own biological treatment plant. It was expensive to install, but the maintenance costs are basically zero... Let's assume the municipality was to come to inspect the situation in our area and other similar places. They would probably discover that $90 \%$ of the sewerage systems do not correspond to modern requirements (wife in a young couple, both educated as biologists, with two children, int. R03).

Such activities indicate the presence of sustainability thinking, and of a frugal yet urbanized approach among the residents (cf. Danielsen et al., 1999). While some residents saw their independence from the authorities as resulting in lower infrastructure-related expenses (i.e. positive), the poor overall state of the infrastructure was an issue that disturbed many. Nevertheless, despite the need for investment in this area, few thought that they would have been able to afford all of the necessary costs. As a result, almost no one complains about the municipality's lack of interest in the living conditions in the neighbourhood; rather, the residents, not the municipalities, initiate most of the current solutions to infrastructural problems.

Of course, there exist also exceptions to this trend as a sign that post-summurbia is diverse. As an official from one municipality explained:

At first, the National Health Board did not allow people to permanently reside there. The main reason was the poor quality of the drinking water. But now, a collective water system has been established in most of the area, as the desire to live there was high and we needed to react (expert from a municipality office, int. M01).

One particular problem is drainage, because summer houses are often situated close to bodies of water or simply in areas subject to seasonal flooding. For a problem such as this, finding solutions can be complicated because the land 
is divided among various owners. The major barrier for comprehensive planning and solutions nowadays lies in the private ownership rights for each plot. Clearly, plot owners attempt to fix the problems within their own boundaries:

After two years of living here, drainage problems appeared. The basement was always full of water and it made the walls rot. I have now filled the basement with gravel and renovated the walls. I hope the problem is solved (middle-aged man living with wife and elderly mother, int. R08).

Although infrastructural problems are the most common reason for communicating with other plot-owners or the municipality, residents only do this when they cannot think of any solutions themselves. Municipalities offer some help to solve problems, but they do not initiate renovation works, even though such problems often require comprehensive investigation and planning. For example, according to Estonian law, municipalities are responsible for ensuring the provision of water and sewerage in densely populated areas, but post-summurbia is still not always officially designated as densely populated.

Municipalities thus challenge whether it is even their task to provide a sewerage system, because settlements are not fully inhabited (which is technically true, but the density is still rather high in most cases). This connects to the overall institutional uncertainty related to planning and extra expenses that municipalities would probably want to avoid (Raagmaa, 2009). This points also to an extreme case of pragmatic planning, or perhaps simply 'non-planning' (cf. Kemp et al., 2007). There is minimum reaction to the problems by the planning authorities, but there should still be at least some step-by-step progress, as hinted at by the following interviewee:

The increase in the residential function makes the water and sewer system issue important. So far, the residents have fixed it, but those areas are not meant for such volumes of wastewater generated by so many residents (expert from a municipality office, int. M04).

Roads are another example of the problems faced by residents. Firstly, overall maintenance is poor, because the roads were not built for intensive use, especially during the non-peak season. Secondly, the legal ownership status of the roads is often unclear. In some cases, roads belong to the municipality, but in many others they have been privatized by the former cooperative, which no longer exists, neither de facto or de jure. In yet other cases, road ownership is shared between the properties, or there are no legallydefined roads, but rather designated segments of plots that, combined together, constitute them. The reasons for this disarray lie in the rapid conduct of land privatization, which caused complex problems in relation to ownership and maintenance responsibilities. Residents often maintain roads despite their messy legal status, just to make access possible. In the best of cases, this is done with the support of the municipality:

After many attempts, we finally wrote a polite and probably reasonable application to get the roadwork done. Before that we collected money from the neighbours and my husband used to be very active in ordering the road-filling material every once in a while. But each time the filling was washed away relatively fast... In fact, the local government saw that we had invested a lot in it by ourselves, but that this was not enough. So, they finally did it [paved the road] two years ago (wife of middle-aged couple with young children, int. R10).
This quotation also suggests that despite the wish for independence from the municipality in finding solutions, residents are most satisfied when the authorities play an important role in renovating roads, putting up streetlights, establishing water and sewerage systems, organizing a school bus route through the neighbourhood, and other services. In hindsight, this type of help from municipalities was seen as having a positive effect. Nevertheless, in areas where systems had not been renovated, residents demanded little input from the municipality, or were even skeptical about it.

Overall, the current planning approach in postsummurbia is rather eclectic. Residents have learned to be creative and to depend on their own resources; indeed, in many ways, they are happy to be independent and free from regulations. One can even recognize a hint of rebelliousness, which is clearly a reaction to the former socialist regulatory planning activities in these settlements. Local planners prefer not to interrupt residents' activities and tend to react only if residents ask first, if even then. Planning regulations are also difficult to enact when the landownership situation is fragmented, while property rights themselves are sacrosanct. Residents have learned to look positively on finding their own creative solutions and to be skeptical about collaboration. In contrast, they have also shown some initiative in cooperating with each other and with the municipality, whenever possible, to find collective solutions. We describe the issues related to collaboration and cooperation in more detail in the following subsection.

\subsection{Communication practices in post-summurbia}

The everyday social dynamics between neighbours highlight tacit local values (Healey, 2003) and form the basis for forging common coalitions for planning ideas. The traditional Soviet summer house community ideal: intensive communication between neighbours; communal working activities in settlements and on each other's plots; and celebrations of national and personal anniversaries (Lovell, 2003), may be what distinguishes the socialist-era summurban lifestyle from its capitalist suburban counterpart. According to the presented analyses, this type of 'dacha community' is a dwindling phenomenon in our sample settlements, quite unlike the situation in the so-called 'garage areas' of the core cities, where gendered community-building practices persist unchallenged (Tuvikene, 2010). Old-style community life persists in post-summurbia when the original summer hut owners are still present. Although old connections and traditions may remain alive, however, they are maintained and practised, respectively, less intensely, or only during the summer months when the seasonal residents arrive:

I am the only person living here [a small cooperative Authors] during winter. In spring, the summerhouse people come and life begins. Everybody manages their own gardens, but the interaction between the neighbours is also intensive. They are all old friends or old friends' children like me (single middle-aged man, int. R05).

The next level of community life could be called 'the new community'. In some areas, new owners have blended into the community and started to interact with other newcomers, who are often from similar life situations (e.g. young couples with children). Communication also provides mutual benefits: older people help look after the children, while young families help the elderly with their everyday needs (e.g. shopping, shovelling snow). These communities, however, often only engage with the more active residents, as one participant told us: 
Sometimes we find ourselves in someone else's garden talking, talking, and talking for hours. But this happens chaotically and in an unplanned way... For the New Year celebration we have a tradition of spending a few hours in different neighbours' homes. But not all the neighbourhood is included, just some close friends (wife in a middle-aged couple with three children, int. R15).

Residents typically form closer relations with only a handful of locals. Such connections are often developed following requests for help in everyday situations - lifting something, building something, transporting something or somebody by car, finding a missing ingredient for cooking, or, not least, solving the shared infrastructure problems in the settlement. In this way, although dwellers do not feel any special need to create a community life in post-summurbia, neither do they reject it if it develops naturally:

We did not know anybody at the beginning. One day, I was baking a cake but discovered at the last moment that I did not have any sugar left. There were only a few people living here at this time. One was an old lady that did not like us; I went to the other house where I had not met the people before. It happened to be a young family like us. We have really started to get along well. We even have a tradition to invite each other for a sauna most weekends (young married mother with one child, int. R10).

There can be hard feelings among residents. Some dwellers have the impression that while others are interacting, they have been left out for some reason. Others feel anxious about the neighbours not being interested in communicating, while prejudice, hostility, and quarrels occasionally damage the social environment:

I was born in Estonia and I know that Estonians are very calm and introverted people... On the other hand, it is also good that they don't stick their noses into our business (wife in an older couple, Russian speaking, int. R12).

Many residents avoid close (or any) communication with their neighbours apart from a simple greeting on the street. They do not know their neighbours and have little interest in them. For these people, home is a private place for family and friends, who often live in the city or who are spread over a larger area. People in this category may lead a very active social life unconnected to the settlement:

Maybe the neighbours interact with each other but we don't. We had bad relations with the one neighbour next to us, but luckily he sold his plot. We have relatives living in the settlement close to here - we interact a lot with them (wife in a young couple with two children, int. R20).

To summarize, the social dynamics between residents in post-summurbia vary by life stage, settlement type and, above all, household. Some people live self-oriented lives, while others have strong ties with their neighbours. In fact, there is no concrete pattern in the evolution of the connections between residents. All groups - newcomers, the elderly, young families, the middle-aged, and retirees communicate to varying degrees. Nevertheless, our interview findings show that residents are mostly satisfied with their communal lives in the studied settlements - be it active or passive - and they enjoy choosing with whom to communicate and establishing their own ways of living. In this respect, post-summurbia characterizes how diverse suburban areas can be (cf. Teaford, 2008).

From a collaborative planning perspective, it is positive that people are largely satisfied with the social dynamics of their home settlements because this makes them more attached to the place, thereby allowing greater commitment to developing community spirit (Healey, 2003). At the same time, however, the diversity in the quality and depth of social connections makes it difficult to listen to all voices and to find consensus among residents, notably concerning feasible planning alternatives. Such diversity also prevents local planning authorities from understanding the social dynamics of settlements. Municipal officials would like to improve communality in these areas, although their perceptions are somewhat blurred by memories of the Soviet-style close-knit summurban communities of the past. Some officials stated that collaboration practices had previously been established by old summurban community members, but in comparison that new plot-owners and residents neither knew about them nor were interested in getting involved. Post-summurbanites consider themselves to be individual landowners and prefer to address their personal problems and solutions to the municipality:

We have established ways and contact persons to communicate with summer house users. But the new residents are not aware of them. They come here and demand whatever they need, not taking into account the overall situation in these settlements (expert from a municipality office, int. M13).

Municipalities would prefer to meet with a representative body of plot owners, to simplify the communication process. Such representative bodies, however, are rare in postsummurbia because the disjointed needs and attitudes of plot owners make forming them difficult. Presented with this situation, municipalities tend to cling to the memory of how things were regulated in Soviet times and are reluctant to find new ways of meeting the diverse needs of modern post-summurbanites. As a result, while it would make the planners' jobs easier if a representative body or even a single representative person for the entire settlement could be found who could stand for everyone's interests, this might be unrealistic for most municipalities:

Summerhouse residents should choose a spokesperson and submit their wishes in a compact form. [However,] we do not even know who to contact there. This would be easier for us and for them (expert from a municipality office, int. M10).

Even though municipal officials are aware of the difficulties involved in collaborating with plot-owners, they rarely take the initiative in terms of planning or renovating infrastructure, preferring to wait until residents contact them:

Residents approach us only when something really annoys them. Otherwise there seems to be no collaboration between them and it is difficult to understand what they need (expert from a municipality office, int. M17).

In part, this attitude in consideration of the municipalities may be due to the fact that they are poorly informed about how problems in post-summurbia are managed, and do not recognize that the limits of residents' activities are generally set by their plot boundaries. In addition, the municipalities' attitude may be due to reservations on the part of the residents themselves: some grass-root ideas for co-financing joint systems with all owners and the municipality have been proposed, but these have been contested by plot owners who fear the new expenses these systems may generate. Our participants did not state that the driving force to live in former summurbia was economic, but the topic was raised repeatedly in relation to the cost of investing in the overall infrastructure. For example, one participant told us: 
We tried to initiate the establishment of a central water and sewerage system at our community meeting in spring. To do things properly, you know... It was really difficult to get people to even start thinking about it. They were afraid that they would have to start paying for their neighbours' water. Many families are very small here and some still use the plot as a summer house (husband in a young family with two children, int. R03).

For their part, residents are not generally interested in the actions of the municipality. They believe that they should resolve technical issues themselves, without reliance on the municipality. Indeed, many residents are ill-disposed towards and distrustful of official bureaucracy in general, and they often only register their residences officially in order to receive small benefits, such as a snow plough in the winter or places in the kindergarten. The following two quotations describe such attitudes:

All our life is related to the city. We work there, the kids go to school and have their sports training there. We don't care about local politics. My wife is only registered here to get the roads cleared of snow in the winter. I am still officially living in town (married middle-aged man with two children, int. R03).

The municipality is all about bureaucracy. We do not need that and can manage here without any help from them (wife of an older couple, int. R06).

Municipality officials claimed to be open to developing ideas about post-summurbia, despite the fact that they had hardly considered them in their planning strategies thus far. They do pay some attention to those areas where the permanent residents outnumber the seasonal ones, but there is still a lack of vision and few practical planning ideas:

Those areas are not specifically addressed in our Master Plan. The residents there have not proposed anything to change that. We support the idea that these areas are becoming more and more residential, but we do not really know how to accommodate the process (expert from a municipality office, int. M16).

We have not considered those areas in our master plan but the opening up of a new group in the kindergarten and renovating the school are definitely related to the needs of the former summer house district (expert from a municipality office, int. M11)

Municipal planners register the signals of self-reliance coming from residents and consider it to be easier to leave the areas as they are, allowing for the spontaneous transformation of these settlements into residential districts. The overall position of planning officials, however, suggests that the existence of a path-dependent planning lock-in where, following the top-down establishment of summurban cooperatives, no further attention is given to such areas.

\section{Conclusions}

This article registers some of the ways in which we can come to understand the challenges of contemporary collaborative planning approaches in suburban residential areas that have experienced the transition from socialistto post-socialist planning practices. Based on the relevant theoretical planning literature, and sensitive to the particular experiences of our case study settlements, we formulated our main research question: How can current understandings and discussions about planning in post-summurbia foster collaborative planning?
Our interviews indicate that post-summurbia is evolving into a fully-fledged form of stable residential suburbia, not least because of the residents' attitudes of self-reliance. The post-summurbanites aversion to their socialist past is vividly manifested in their somewhat rebellious activities. This desire for self-reliance also suits the local municipalities, who are weakly positioned in a 'neoliberal' planning context. The outcome of this situation is that post-summurbs are spontaneously being redrawn as residential districts, with the interests of local residents at the forefront and with little guidance or control being offered by the local municipalities. Moreover, the relative success of such a transformation thus far seems to have strengthened the autonomy of the residents, further weakening the role of planning.

Still, planning needs to reassert its status because of the environmental, infrastructural and social problems the residents themselves bring out in our interview study. In practice, the post-summurban residents' spontaneity and self-sufficiency affect the environment significantly, but their independent activities and rejection of the authorities have resulted in the near-absence of general perspectives and planning. This, combined with the passivity of the authorities, has prevented planning from playing a more active role: problems are solved only when they cry out loud or are presented within a politically powerful framing.

Our study confirms the tendency to listen to unequal voices, which is a classical focus of critiques of collaborative planning (Healey, 2003). The challenge for planners lies in seeing the bigger picture of post-summurban development. The municipal officials interviewed in this study are, of course, also affected by the post-socialist attitudes of rejecting comprehensive planning altogether. It appears that this stance inhibits them from seeing the alternatives that lie between the two extremes of comprehensive planning and non-planning.

The responsibility to foster the communicative approach in post-summurbia rests heavily on the local planning agents. Their passive attitudes have stayed in limbo for a long time, but they are probably connected to the wider problems of unclear institutional assignments and budget decisions (Raagmaa, 2009), or to the fact that professional planning education has developed slowly in Estonia (Adams et al., 2014).

The present study shows that in order to launch collaborative planning in post-summurbia, it should be brought back to its roots in pragmatic philosophy. The residents' learned experiences of self-sufficient problemsolving are a valuable untapped resource for planning in these settlements. This uniqueness is worth preserving as it has made the locals bond to their living places in multidimensional ways. They are strongly motivated to develop post-summurbia as a liveable and sustainable environment. The main obstacle in these areas consists of the tensions between individualism and self-sufficiency versus the willingness to demand or accept municipal investment in the improvement of the public infrastructure. The main challenge for planning is to take the lived experiences, resources and needs of the residents seriously. How this can be done is an issue that requires further research.

\section{Acknowledgements}

We are especially grateful to all participant households and the civil servants from the municipalities we visited. Thank you, Anneli Kährik and Helen Lainjärv, for participating in 
our fieldwork as interviewers, and to Siiri Silm for technical help with the methodology and figures. We also thank two anonymous reviewers for their valuable comments. The main part of the fieldwork for this research was financed by the European Social Fund (project No. 1.5.0109.09-0031). The authors also acknowledge financial support provided by the Estonian Ministry of Education and Science (target financed research project nos. SF0180052s07 and SF0180049s09) and a grant from the Estonian Science Foundation (No. 9247).

\section{References:}

ADAMS, N., COTELLA, G., NUNES, R. (2014): The Engangement of Territorial Knowledge Communities with European Spatial Planning and Territorial Cohesion Debate: A Baltic Perspective. European Planning Studies, 22(4): 712-734.

ALLMENDINGER, P., TEWDWR-JONES, M. (2002): The Communicative Turn in Urban Planning: Unravelling Paradigmatic, Imperialistic and Moralistic Dimensions. Space \& Polity 6(1): 5-24.

ALTROCK, U., GÜNTNER, S., HUNING, S., PETERS, D. [eds.] (2006): Spatial Planning and Urban Development in the Ten New EU Member States. London, Ashgate.

BATER, J. H. (1980): The Soviet City: Ideals and Reality. London, E. Arnold.

BRADE, I., SMIGIEL, C., KOVÁCS, Z. (2009): Suburban Residential Development in Post-socialist Urban Regions: The Case of Moscow, Sofia, and Budapest. In: German Annual of Spatial Research and Policy 2009 (pp. 79-104). Berlin, Heidelberg, Springer.

BRAND, R., GAFFIKIN, F. (2007) Collaborative Planning in an Uncollaborative World. Planning Theory 6(3): 282-313.

BRUNS, D. (2007) Tallinna peaarhitekti mälestusi ja artikleid [The memories and articles by the Cheaf Architect of Tallinn]. Tallinn, Greif OÜ.

CRANG, M., COOK, I. (2007): Doing Ethnographies. London, Sage Publications.

DANIELSEN, K. A., LANG, R. E., FULTON, W. (1999): Retracting Suburbia: Smart Growth and the Future of Housing. Housing Policy Debate 10: 513-540.

DUANY, A., PLATER-ZYBERK, E., SPECK, J. (2000): Suburban Nation: The Rise of Sprawl and the Decline of the American Dream. NewYork, North Point Press.

FIALOVÁ, D. (1999): Second homes in the hinterland of Prague and possibilities of their transformation for permanent houses. Acta Facultatis Rerum Naturalium Universitatis Comenianae: Geographica 2(II): 213-221.

FORESTER, J. (1989): Planning in the Face of Power. Berkeley, University of California Press.

FORSYTH, A. (2012): Defining Suburbs. Journal of Planning Literature 27(3): 270-281.

FRENCH, R. A. (1995): Plans, Pragmatism and People: The Legacy of Soviet Planning for Today's Cities. London, UGL Press.

GOLUBCHIKOV, O. (2004): Urban planning in Russia: towards the market. European Planning Studies 12(2): 229-247.

GOLUBCHIKOV, O. (2006): Interurban Development and Economic Disparities in a Russian Province. Eurasian Geography and Economics 47(4): 478-495.
GRANT, J. (2009): Theory and Practice in Planning the Suburbs: Challenges to Implementing New Urbanism, Smart Growth and Sustainability Principles. Planning Theory and Practice 10(1): 11-33.

HEALEY, P. (2003): Collaborative Planning in perspective. Planning Theory 2(2): 101-123.

HEALEY, P. (2009): The Pragmatic Tradition in Planning Thought. Journal of Planning Education and Research 28(3): 277-292.

HIRT, S. (2007): Suburbanizing Sofia: characteristics of post-socialist peri-urban change. Urban Geography 28(8): 755-780.

HIRT, S., STANILOV, K. (2009): Revisiting Urban Planning in Transitional Countries. Regional study prepared for Revisiting Urban Planning: Global Report on Human Settlements 2009 [online]. Available at: http://www. unhabitat.org/grhs/2009

HUXLEY, M., YIFTACHEL, O. (2000): New Paradigm or Old Myopia? Unsettling the Communicative Turn in Planning Theory. Journal of Planning Education and Research 19(4): 333-342.

INNES, J. E., BOOHER, D. E. (2010): Planning with Complexity: An Introduction to Collaborative Rationality for Public Policy. London, Routledge.

IOFFE, G., NEFËDOVA, T. (1998): Environs of Russian Cities: A Case Study of Moscow. Europe-Asia Studies 50: 1325-1356.

KEMP, R., LOORBACH, D., ROTMANS, J. (2007): Transition management as a model for managing processes of co-evolution towards sustainable development. International Journal of Sustainable Development \& World Ecology 14(1): 78-91.

LAWRENCE, D. P. (2000): Planning theories and environmental impact assessment. Environmental Impact Assessment Review 20: 607-625.

LEETMAA, K., NUGA, M., KÄHRIK, A., SILM, S. (2011): Muutused nőukogudeaegsetes suvilapiirkondades, nende kujunemine elamurajoonideks ja roll eeslinnastumises Tallinna ja Tartu linnaregioonides ["Socialist summer home settlements in post-socialist suburbanization"]. Estonian Social Fund, grant report, No 1.5.0109.09-0031.

LEETMAA, K., BRADE, I., ANNISTE, K., NUGA, M. (2012): Socialist Summer-home settlements in Post-Socialist Suburbanization. Urban Studies 49(1): 3-21.

LOVELL, S. (2003): Summerfolk. A History of the Dacha, 1710-2000. Ithaca, Cornell University Press.

MASON, R. J., NIGMATULLINA, L. (2011): Suburbanization and Sustainability in Metropolitan Moscow. The Geographical Review 101(3): 316-333.

NÆSS, P. (2001): Urban Planning and Sustainable Development. European Planning Studies 9(4): 503-524.

OUŘEDNÍČEK, M. (2007): Differential Suburban Development in the Prague Urban Region. Geografiska Annaler Series B 89: 111-126.

PÓCSI, G. (2011): Land use change of the 'small hobby gardens' in the peri-urban area of Szeged, Hungary. Forum geografic. Studii şi cercetări de geografie şi protectia mediului 10(2): 312-321.

RAAGMAA, G. (2009): Planning theories and development practices. Past-dependencies contra new ideology: Impact of planning for sustainable housing 
development. In: Holt-Jensen, A., Pollock, E. [eds.]: Urban Sustainability and Governance: New Challenges in Nordic-Baltic Housing Policies (pp. 79-99). New York, Nova Science.

ROOSE, A., KULL, A. (2012): Empowering Spatial Information in the Evolution of Planning Systems: Lessons of ad-hoc Plans in Estonia, Regional Studies, 46(4): 493-508.

ROOSE, A., KULL, A., GAUK, M., TALI, T. (2013): Land use policy shocks in the post-communist urban fringe: a case study of Estonia. Land Use Policy 30(1): 76-83.

ROSENHEAD, J. (1980): Planning Under Uncertainty: 1. The Inflexibility of Methodologies. The Journal of the Operational Research Society 31(3): 209-216.

RUDOLF, R., BRADE, I. (2005): Moscow: Processes of Restructuring in the Post- Soviet Metropolitan Periphery. Cities 22: 135-150.

RUOPPILA, S. (2007): Establishing a Market-orientated Urban Planning System after State Socialism: The Case of Tallinn. European Planning Studies 15(3): 405-427.

SAMARÜÜTEL, A., SELVIG, S., HOLT-JENSEN, A. (2010): Urban sprawl and suburban development around Pärnu and Tallinn, Estonia. Norsk Geografisk Tidsskrift - Norwegian Journal of Geography 64(3): 152-161.

SHAW, D. J. B. (1979): Recreation and the Soviet City. In: French, R. A., Hamilton, F. E. [eds.]: The Socialist City: Spatial Structure and Urban Policy (pp. 119-144). Chichester, John Wiley and Sons.

SHOMINA, E.S. (1992): Enterprises and the urban environment in the USSR. International Journal of Urban and Regional Research 16(2): 222-233.

SIMPSON, F., CHAPMAN, M. (1999): Comparison of Urban Governance and Planning Policy: East Looking West. Cities 16(5): 353-364.
SMITH, D. M. (1996): The Socialist City. In: Andrusz, G., Harloe, M., Szelenyi, I. [eds.]: Cities after Socialism: Urban and Regional Change and Conflict in Post-socialist Societies (pp. 70-99). Oxford, Blackwell Publishers.

TAMMARU, T., LEETMAA, K., SILM S., AHAS, R. (2009): Temporal and Spatial Dynamics of the New Residential Areas around Tallinn. European Planning Studies 17(3): 423-439

TEAFORD, J. C. (2008): The American suburb. New York, Routledge.

TSENKOVA, S. (2010): Informal Settlements in PostCommunist Cities: Diversity Factors and Patterns. Urbani izziv 21(2): 73-84.

TSENKOVA, S. (2011): Venturing into Unknown Territory: Strategic Spatial Planning in Post-Communist Cities. Urbani Izziv 22(1): 83-99.

TSENKOVA, S. (2014): Planning trajectories in postsocialist cities: patterns of divergence and change, Urban Research \& Practice, 7(3): 278-301.

TUVIKENE, T. (2010): From Soviet to post-Soviet with transformation of the fragmented urban landscape: The case of garage areas in Estonia. Landscape Research 35(5): 509-528.

VÁGNER, J., MÜLLER, D. K., FIALOVÁ, D. (2011): Second home tourism in light of the historical-political and socio-geographical development of Czechia and Sweden. Geografie 116(2): 191-210.

\section{Expert Interviews:}

NIINEVÄLI, E. (2011): Architect-specialist, has worked in Estonian Building Commettee, Department of Rural Construction during 1966-76. Interview carried out on $20^{\text {th }}$ September 2011 in Tallinn.

SIHT, A. (2011): Architect-specialist, has worked in Estonian Building Commettee during 1979-91. Interview carried out on $8^{\text {th }}$ September 2011 in Tallinn.

Initial submission 15 November 2014, final acceptance 21 July 2015

Please cite this article as:

NUGA, M., METSPALU, P., ORG, A., LEETMAA, K. (2015): Planning post-summurbia: From spontaneous pragmatism to collaborative planning? Moravian Geographical Reports, 23(4): 36-46. DOI: 10.1515/mgr-2015-0023. 